\title{
French reaction to the menace from Cabanos and Bonis within the litigious territory between Brazil and French Guiana (1836-1841) ${ }^{1}$
}

\section{Reação francesa às ameaças Cabanos e Bonis no território litigioso do Amapá (1836- 1841)}

DOI: http://dx.doi.org/10.1590/2236-463320161408

Débora Bendocchi Alves

Instituto de História Ibérica e Latinoamericana (IHILA) Faculdade de História da Universidade de Colônia, Colônia, Alemanha dbendocc@uni-koeln.de

\begin{abstract}
This article will analyze an historical episode that occurred between 1836 and 1841 during the French occupation of the disputed territory located between Brazil and French Guiana. I intend to consider two regional factors that influenced the decision of both the Cayenne Government and the metropolitan government to build military forts in the region. Such factors are the Cabanagem and the attempts of black Bonis to settle in Lower Oiapoque. I will go on to show that the French withdrawal from Amapá Lake in 1840, but not from the post on the right bank of the Oiapoque River, was due not only to international and diplomatic factors but also had regional causes. Notwithstanding the French government's interests in expanding the territory of its South American colony, I want to draw attention to the threats - real or fictitious - of Cabanos, from Brazil, and black Bonis, from Dutch Guiana.
\end{abstract}

\footnotetext{
${ }^{1}$ This article forms part of a research project funded by Gerda Henkel Foundation (Germany) about the region of the French-Brazilian Boarding between 1840-1900. It is a revised and extended version of my participation at the ANPUH 2015 XXVIII National History Symposium, held in Florianópolis.
} 
Resumo: Gostaria de ampliar neste artigo a análise de um episódio histórico ocorrido entre 1836 e 1841: a ocupação francesa do território litigioso situado entre 0 Brasil e a Guiana Francesa. Pretendo considerar dois fatores regionais que, a meu ver, influenciaram a decisão tanto do governo de Caiena como do governo metropolitano de construir fortes militares na região. Tais fatores são a Cabanagem e as tentativas dos negros Bonis de se instalarem no baixo Oiapoque. Entendo também que a retirada francesa do lago do Amapá, em 1840, mas não do posto à margem direita do rio Oiapoque, se deva não só a fatores internacionais e diplomáticos como também a questões de ordem regional. Não querendo negar os interesses do governo de Paris de expandir o território de sua colônia sul-americana, pretendo chamar a atenção para as ameaças - reais ou fictícias - dos Cabanos ${ }^{2}$ e dos negros Bonis, provenientes da Guiana Holandesa.

Keywords: Brazil-French Guiana border; Cabanos and Bonis; runaway slaves

Palavras-chave: fronteira Brasil-Guiana Francesa; Cabanos e Bonis; escravos fugidos.

\section{Introduction}

During my readings about the conflicts between the Empire of Brazil and France, concerning the northeastern border of the Guianas in the middle of the XIX Century, I have encountered brief narratives about the French occupation, in 1836, of the territory considered by the Treaty of Utrecht (1713) as belonging to Portugal and later to Brazil, but according to the Treaty of Amiens (1802), it was considered as French. Initially, in 1835 , the French claimed the establishment of a military deployment in the Amapá Lake for the civil conflict which was devastating Pará. Henceforth, they had the need to solve the issue of the limits, which was pending for centuries. ${ }^{3}$

\footnotetext{
${ }^{2}$ About the meaning of the expression Cabano, see the works of LIMA, Leandro Mahalem. Rios Vermelhos. São Paulo: Faculdade de Filosofia, Letras e Ciências Humanas, Universidade de São Paulo, São Paulo, 2008, Tese (M estrado em Antropologia). It is interesting to notice that Caetano da Silva, in 1860, did not use the expression Cabano to designate the rebels. He referred to them as a bunch of insurgents from the inner part of the province. SILVA, Joaquim Caetano da. 0 Oiapoque e o Amazonas: uma questão brasileira e francesa. Campinas: IFCH - UNICAMP/ Secult, 2010. (4 edição organizada e coordenada por Paulo Miceli e Janaina Camilo).

${ }^{3}$ REIS, Arthur Ferreira. A Amazônia e a cobiça internacional. Rio de Janeiro: Record Editora, 1968.
} 
In my opinion, when evaluating the causes of the establishment, in 1836, of a French military force in a territory considered as belonging to the Empire of Brazil, the Brazilian historiography focused their analysis in the imperialist intentions of France, considering the interests of territorial expansion of the country in the American continent. Such interpretation is mainly based on the works of Duarte da Ponte Ribeiro, who, in 1842, had written that the French audacity had no limits and the country, with the rebellion in 1835 in the province of Pará, found the opportunity to bring back the old commitment to expand their colony up to the Amazon River. In his Detailed Statement, Ponte Ribeiro explained thoroughly the diplomatic controversies between both empires, considering that the French have used the rebellion in Pará (1835-1840) simply as an excuse for the need to prevent the contact of the anarchists with the inhabitants of the French Guiana. ${ }^{4}$ Even in the excellent work of Joaquim Caetano da Silva, L'Oyapoc et I'Amazonie: Question Brésilienne et Française, published in Paris, in $1861,{ }^{5}$ where the author chronologically rebuilds each diplomatic step of the conflict, the causes of this episode of history are restricted only to the French expansionist ambitions. This interpretation will be resumed by Arthur Reis and prevails practically to the present day. ${ }^{6}$ As the analysis of the authors seemed to be very simplistic and unilateral, I decided to refer to the primary sources, especially the French ones, and the geographical maps.

Rereading the official documents from that time, it can be noted that, besides Cabanagem, there were other bordering factors which certainly contributed to the French decision of establishing military posts in the territory considered to be Brazilian, that is, between the Oiapoque and Amazonas Rivers. I consider the several unsuccessful negotiation attempts of the Bonis from the Dutch Guiana with the Cayenne Government, between 1836 and 1841, in order to settle in the Camopi River, a tributary of the Oiapoque River, as one of the reasons that led the governors from Cayenne to take actions to, as the governor Laurens de Choisy used to say, protect the

\footnotetext{
${ }^{4}$ RIBEIRO, Duarte da Ponte. Exposição circunstanciada do estado das negociações entre o Brasil e a França sobre terrenos contestados pelo lado do rio Oyapock. Rio de Janeiro, 4 de março de 1842. Biblioteca Nacional. Rio de Janeiro, Brasil. Seção de Manuscritos.

${ }^{5}$ SILVA. Op. Cit., p. 149-161.

${ }^{6}$ REIS, Arthur Ferreira. Op.cit., p. 106-107; Idem: Território do Amapá. Rio de Janeiro: Imprensa Nacional, 1949, p. 92-93.
} 
Guiana residents ${ }^{7}$ and avoid the proliferation of ideas of freedom and rebellion among the French slaves. ${ }^{8}$ In 1836, Choisy established a military post in the biggest island of the Amapá Lake ${ }^{9}$ to avoid, as he said, the arrival of the Pará insurgents in the Guiana; in 1837 , he installed a garrison in the island of Cafésoca - on the French side of the river - and, in 1838, the Bottom Post, named as Malouet Fort from 1840 on, on the right bank of the Lower Oiapoque River, both to protect the residents of the forays of black Bonis. ${ }^{10}$ Furthermore, on the part of the Guiana governors ${ }^{11}$, there was the idea that it was necessary to colonize the South region of Oiapoque, once they considered it rich and appropriate for the economical development of the colony. For them, therefore, besides the function of protecting the French settlers from the Pará rebels, the Amapá military post should serve as a base for the beginning of a French settlement in the area.

Primarily, with this article, I intend to reconsider the multiplicity of factors leading to diplomatic conflicts between Brazil and France, then seeking to integrate and connect the different dimensions of this bordering experience. Such dimensions influenced the long process of demarcation of the northeastern border of the Amazon and, consequently, the movement of the local population who, in their own way, knew how to use this vast area in dispute for a long time and for their own profit. I do not intend to get into the matter of land rights, regulated by the several international treaties, nor into the matter of the lengthy process of demarcation of the border between Brazil and the French Guiana, which only took place in 1900. I will look only

\footnotetext{
${ }^{7}$ In French, habitants refer to the land owners in the documents presented in this article. In 1832 there were 469 habitants proprietaires, and only 82 were considered as big landowners with more than 100 slaves. FOUCK, Serge Mam Lam. La Guyane française au temps de l'esclavage, de l'or et de la francisation (1802-1946). Guadeloupe: Iris Rouge Editions, 1999, p. 11.

${ }^{8} \mathrm{CHOISY}$, Laurent. Letter to the Ministry of the Navy and the Colonies, January 12th, 1836. Archives Nationales d'Outre-M er (ANOM), Fonds Ministériel (FM), Série Géographie (SG), carton GUY 10, Dossier A3 (02).

${ }^{9}$ WALCKENAE, Barão de. Mémoire sur les nouvelles découvertes geographiques faites dans la Guyane Française et sur le nouvel établissement formet à l'île de Mapa. Nouvelles Annales des Voyages. Dixneuvième année, 1837, p. 11.

${ }^{10}$ HURAULT, Jean. Histoire des noirs réfugiés Boni de la Guyane française. Revue française d'histoire d'outre mer, tome 47, n. 166, premier trimestre, 1960, p. 76-137.

${ }^{11}$ The governors from Guiana were officers from the French navy or part of the civil administration of the Ministry of the Navy and the Colonies. Those captains or commissioners of the navy hold the office of Governor for three years and had a difficult task, among the government requirements and the interests of the habitants proprietaires. Many of the habitants had administrative roles or were members of the Colonial Council, created in 1833, sharing the legislative capacity of the settlement with the legislative power of the realm. FOUCK. Op. Cit., p. 16.
} 
into the events concerning the border region between 1835 and 1841. Even though the objective of this article is not to deal with Cabanagem, some lines about the movement will help the reader to contextualize and better understand the primary sources consulted.

\section{Cabanagem and its facts}

Cabanagem, in Grão-Pará, is one of the so-called rebellions of the Regency Period (1831-1840), being considered by many historians as the most remarkable, stressful, conflicting and bloody movement occurred in Brazil. ${ }^{12}$ It was the longest rebellion of the period against the Imperial Government and it reached up a vast area of the national territory. It was the only one where the rebels controlled, for a long time, the state apparatus of the province and had taken the capital, Belém, for three times. Among all rebellions of the period, this was the one putting more at risk the territorial integrity of the Empire, being brutally repressed by the central government. ${ }^{13}$

Since the beginning of the 19th century, the Amazon region was the stage for rebellions and internal upheavals arising from the political and economical dissatisfaction of the regional Brazilian elite after the Independence of Brazil and/or the exploitation and enslavement of the indigenous, mixed races, and black population of the province. ${ }^{14}$ Cabanagem was a movement without a well-defined beginning and end, but we can say that the acute stage began in January 1835 and ended in $1840 / 41.15$

The unpopularity of Bernardo Lobo de Souza, president of the province since 1833, was intensified when he decided to recruit the "inconvenient" elements, that is, the opponents of the government for the Army or the Navy Forces of the Empire. In January 7 th, 1835, the president and the weapons commander of the province, both

\footnotetext{
12 PRADO JÚNIOR, Caio. Evolução Política do Brasil e outros estudos. São Paulo: Ed. Brasiliense, 1977 (1 edição, 1933), p. 69; CLEARY, David. "Lost Alltogether to the Civilized World". Race and the Cabanagem in Northern Brazil, 1750 to 1850. Comparative Studies in Society and History, v. 40, n. 1, Jan. 1998, p. 109-135; HARRIS, Mark. Rebellion on the Amazon: The Cabanagem. Race and Popular Culture in the North of Brazil, 1798-1840. New York: Cambridge, 2010.

${ }^{13}$ CLEARY, Op. Cit., p. 111-112.

${ }^{14}$ About the Cabanagem historical background: PINHEIRO, Luís Balkar Sá Peixoto. De vice-reino à Província: tensões regionalistas no Grão-Pará no contexto da emancipação política brasileira. Somanlu. Revista de Estudos Amazônicos, v.1, n, 1, 2000, p. 83-107,

${ }^{15}$ Ibidem, p. 121.
} 
designated by the Regency, were murdered by organized groups which invaded Belém from Acará. Felix Clemente Malcher, one of the leaders of the rebellion, became president of Pará and Francisco Vinagre was appointed as Weapons Commander. The rebellion situation in the province was not relieved by the seizure of power by Malcher, a large mill and slaves owner. Due to disputes between internal factions of the movement, Malcher was murdered in February 1835, and Francisco Vinagre was designated as the second president of the province. The insurgents could keep in power up to the designation of the Marshal Manuel Jorge Rodrigues by the Empire, in June 26th. The situation got worse with the battles in August 1835, when 70 white people were slaughtered in the city of Vigia. As of the mid of the year, the violence would reach the inner part of the province, with an openly racial content. Several black slaves murdered their masters and ran away, mostly to the island of Marajó. ${ }^{16}$ Marshal Rodrigues, with the help of the legalistic troops sent by the Regency, tried to prevent the rebels to step forward, albeit without success, being obliged to leave the capital and set up the Legalistic Government in the island of Tatuoca. Francisco Vinagre died during the battles in August and Belém was under the command of the young Eduardo Nogueira Angelim, one of the leaders of the rebels that could remain in this post for nine months. In May, 1836, Angelim and his group were forced to leave Belém due to lack of ammunition, as the imperial government had blocked the city, with the help of foreign fleets. In April 19th, 1836, Marshal Rodrigues was replaced by the Brigadier Francisco J osé de Sousa Soares d'Andréa, who arrived to the island of Tatuoca and took over the province presidency. Born in Portugal, Soares d'Andréa arrived with a naval force and a troop comprised of 800 men. Coming from Pernambuco, a brigade of the Army, with 500 men, joined them. Since then, the peace process - or, according to several historians, a war of extermination - began ${ }_{1}^{17}$ originally in the capital and then in the countryside. Soares d'Andréa decimated the insurgents under the Angelim command, arrested Angelim and his brothers, and started to put the city of Belém in

\footnotetext{
${ }^{16}$ For more information about the presence of black people in the Cabano movement, see, among others, the works of SALLES, Vicente. 0 Negro no Pará, sob o regime da escravidão. Rio de Janeiro, FGV e UFPA, 1971; PINHEIRO, Luiz Balkar. Nos subterrâneos da revolta: trajetórias, lutas e tensões na Cabanagem. São Paulo: PUC-SP, 1998, Tese (Doutorado em História); BEZERRA NETO, José Maia. Ousados e insubordinados: protesto e fugas de escravos na Província do Grão-Pará - 1840/1860. Topoi, Rio de Janeiro, v. 2, 2001, p. 73-112.

${ }_{17}$ CLEARY. Op. Cit., p. 127.
} 
order: he created a police force, a cavalry squadron and split the province in nine military commands; he also created the Body of Employees (Corpos de Trabalhadores), enlisting all unemployed, among them the rebels which were not criminals. As we will see further, the province was considered pacified from this moment on, although there were still rebel groups in the inner part of the Amazon. In March 25th, 1840, with the surrender of the last leader of the rebels, Jorge de Magalhães, Cabanagem was considered as finished. ${ }^{18}$

This article is not intended to address the different analyses about who were the Cabanos and what they were claiming. In general, we can say that the rebels belonged to several social groups: a regional elite with people born in Brazil, Tapuias ${ }^{19}$, several indigenous groups, black slaves and freed people and many other people of mixed races. ${ }^{20}$ Those different segments of society in Pará often presented a diverse political ideal from one another. Leandro Lima believed that the leaders of the movement fought to ban the Luzo-Brazilians and other occupants of the main administrative positions in Grão-Pará. The rebels from the countryside tried to keep or (re)create the forms of socio-political-cosmological organization, which were different from the refoundation of the State aimed by the Cabano leaders. ${ }^{21}$ In relation to the participation of black people, both slaves and freed, Bezerra Neto states that "the supporters of general and unrestricted freedom for everyone used to see the movement in their own way, trying to inject radicalism to it, differing from the moderate sectors of the Cabanagem". ${ }^{22}$ Therefore, the Cabanos formed a heterogeneous group, comprised of people from different origins and socio-cultural formations, with different claims and objectives.

\footnotetext{
${ }^{18} \mathrm{Magda} \mathrm{RICCl}$ made a great summary of the facts and a bibliographical overview about Cabanagem in the article Llagas de guerra y actos de fe política: La "Cabanagem" en la narrativa historiográfica y antropológica. Boletín Americanista, Año LXII, 1, n. 64, Barcelona, 2012, p. 33-57.

${ }^{19}$ Tapuias or tapuios were the indigenous people who inhabited the region for one or more generations and who spoke the Amazon general language, Nhéengatú. They passed through all types of forced label. LIMA. Op. Cit., p. 295.

${ }^{20}$ About the groups involved in the movement, especially from the Amazonian inner part, see: HARRIS, Mark. Op. cit.

${ }^{21}$ LIM A. Op. Cit., p. 241.

22 BEZERRA NETO. Op. Cit., p. 77.
} 


\title{
3. Official Brazilian and French documents
}

\subsection{Ministry and Government Reports from the province of Pará}

The first reference about the decision of the French government to occupy the southern part of the Oiapoque River can be seen in a report called "Relatório do Ministério dos Negócios do Estrangeiro do Brasil" (Report of the Brazilian Ministry of Foreign Affairs), from 1835. It is recorded that the Brazilian Government asked for an explanation about the order the Minister of the French Navy sent to the Guiana, commanding the provisional establishment of a military post on the right bank of the Oiapoque River. The Duke of Broglie, Chairman of the Board and French Ministry of Foreign Affairs, by means of his Envoy, sent to the Brazilian court, provided "the clarification to the Imperial Government which was accepted at that time due to the stage of the rebellion occurring in the province of Pará". ${ }^{23}$ It was acceptable that the French Government wanted to "preserve the French owners about the bloody upheavals happening in the province of Pará." 24

In 1836, there was an addendum in the justification of the French Government for the same fact. According to the report:25

\begin{abstract}
It is preserved, yet, the provisional establishment that the government of His Majesty, King of the French, determined to be made on the right bank of the Oiapoque River; and, although the Brazilian Minister in Paris and the President of the Province of Pará had demanded the withdrawal of the military post, the Minister of Foreign Affairs of His Most Christian Majesty did not agree with this complaint, not only to protect the French properties, because of the restless state of the province, but also because of the need to set the boundaries between the Empire and the French Guiana. The Imperial Government, having given the appropriate instructions to the Minister in Paris, expect them to get the best result. ${ }^{26}$
\end{abstract}

In 1835, the establishment of a provisional post was due to the upheavals in the province of Pará, a justification considered as credible and acceptable by an enslaving monarchist. From 1836, the explanation included the issue of territorial boundaries, a justification not accepted by the Brazilian Empire. It is interesting to notice that the

\footnotetext{
${ }^{23}$ M inistry of Foreign Affairs, Minister José Ignácio Borges. Report from the year of 1835, presented to the Legislative General Assembly during the Ordinary Session in 1835. Published in 1836.

${ }^{24}$ SILVA. Op. Cit., p. 150.

${ }^{25}$ To simplify the reading, I updated the orthography of the primary sources.

${ }^{26}$ Ministry of Foreign Affairs, Minister Antonio Paulino Lima de Abreu. Report from the year of 1836, presented to the Legislative General Assembly during the Ordinary Session in 1837.
} 
Brazilian historiography dates as 1836, and not 1835, as the beginning of the disagreement between the Government of both countries, because it was only from 1836 on that the French started to require the set the boundaries, an outstanding issue for centuries. ${ }^{27}$ Whilst the issue is based on the protection of the French subjects against the rebels in Pará, the French could count on the understanding of the Brazilian authorities. The conflict was only a part of the diplomatic agenda when it inserted the issue of the border demarcation.

According to the Brazilian government, in 1837, the Pará province was pacified, the order had been established in the most part of the territory, mainly in the locations which were contiguous to the French colony. As the official reasons presented by the French for the occupation were suspended,

\footnotetext{
...the Empire Government decided to draw the attention of the Envoy Extraordinary and Minister Plenipotentiary of His Majesty the King of the French alongside the Imperial Court about the outstanding condition of that portion of the Brazilian territory, willing to end and conclude the discussion of this serious matter; which became more complicated after the idea to include this matter of fact with the boundaries issue... ${ }^{28}$
}

In the Report from 1838, it can be observed that Brazil continued to required the withdrawal of the French soldiers from the Brazilian territory, but, from this year on, the minister mentioned military posts, in plural form. Thus, we can assume there were more than one post. To prove that the lands between the Oiapoque and Amazon Rivers belong to Brazil, the 8th Article of the Treaty of Utrecht (1713) was always mentioned, and also the Vienna Treaty (1815) and the 1817 Paris Convention, without result. The French insisted in the demarcation of boundaries, considering the territory where the military posts were located as belonging to them, and their allegations were based on the Treaty of Amiens, from 1802.

It is interesting to note that, although the annual reports from 1837 on stated that the order was restored in Pará, and, therefore, the French allegations were no longer justified, it is clear that the situation was no good, according to the speech of the President of the Pará province. Even though highlighting the relative peace in the

\footnotetext{
27 REIS. Território do Amapá ... Op. Cit., p. 93; A Amazônia e a cobiça internacional ... Op. Cit., p.106- 107. ${ }^{28}$ M inistry of Foreign Affairs, Minister Antonio Peregrino Maciel Monteiro. Report from the year of 1837, presented to the Legislative General Assembly during the Ordinary Session in 1838.
} 
province, Soares d'Andrea, President of Pará, accused the persistence of rebel movements in certain areas. During his speech in March 2nd, 1838, he said he was able to pacify the capital, the entire part including the Salgado coast to Maranhão, that he conquered the large Joanes Island, arrested the main rebels and prepared to achieve peace for the whole area of the Lower Amazon. He said that, at that time, everything was calm, except the Tapajós and Curuá Rivers, and some points or channels around Breves, where small rebel groups could easily shelter and hide, because of the small number, disturbing the peace..$^{29}$ Therefore, even if the restoration of peace in Pará appeared in the annual reports of the Ministry of Foreign Affairs, the French had their own reasons to remain in the territory for security reasons, based on the local situation.

In relation to the border issues with the French Guiana, Soares d'Andrea accused the French once again. According to his own words:

\begin{abstract}
The French Government, taking advantage of the Brazilian frailty due to the political upheaval and, mainly, to the extinction of the Armed Force, which has caused enormous tragedies, brought back old pretensions, that today are unfounded, about the boundaries; and claiming that the Oiapoque boundaries were around three degrees to the south of the river bank, he required a strong deployment of two hundred front line men and two warships in Amapá, using as an excuse for this expressed invasion the intention to ensure they were against the communication of the beginnings of a voracious anarchy that was devastating Pará. ${ }^{30}$
\end{abstract}

In 1838, the Minister of Foreign Affairs asked the representative of the Brazilian Empire in Paris to urgently require the withdrawal of the military posts of the French Government, otherwise he would not negotiate the borders, as proposed by the Tuileries office. ${ }^{31}$ The pressures of the Brazilian diplomacy seemed to be effective, because the 1839 Report shows that the French Government decided to leave the post in Amapá and, as agreed, they would be in charge of the designation of the boundaries commissioners, expecting equal measure from Brazil, aiming to execute a definitive demarcation, according to the Convention as of August 28th, 1817. The Minister

\footnotetext{
${ }^{29}$ Speech of the President of the Pará Province in the 1st Session of the Provincial Assembly, in March 2nd, 1838. Santos Restored Typography (undated).

${ }^{30}$ Ibidem.

${ }^{31}$ Ministry of Foreign Affairs, Minister Cândido Baptista de Oliveira. Report from the year of 1838, presented to the Legislative General Assembly during the Ordinary Session in 1839.
} 
ensured that the Empire Government would start the demarcation, as soon as the Brazilian territory was completely unoccupied by the French. ${ }^{32}$ In 1840, Minister Aureliano de Souza Coutinho highlighted that the French Government had determined the full eviction of the territory, but they did not designate the commissioners to establish the boundaries. The Brazilian government had already designated their commissioners, but they considered appropriate to wait for the official information that the French Government had indicated their own commissioners and that they were close to leave to the Guiana. ${ }^{33}$ The 1841 report regarding this issue is exactly the same from the 1840 text, which clearly means that the situation did not change. ${ }^{34}$ Even though there were no mentions to the issue with the French, in July 10th, 1840, the evacuation of the Amapá post had been completed ${ }^{35}$ and, in July 1841, with the intervention of the Great Britain, according to Ponte Ribeiro, and with the British pressure, the neutralization of the territory disputed between Brazil and France was agreed. ${ }^{36}$

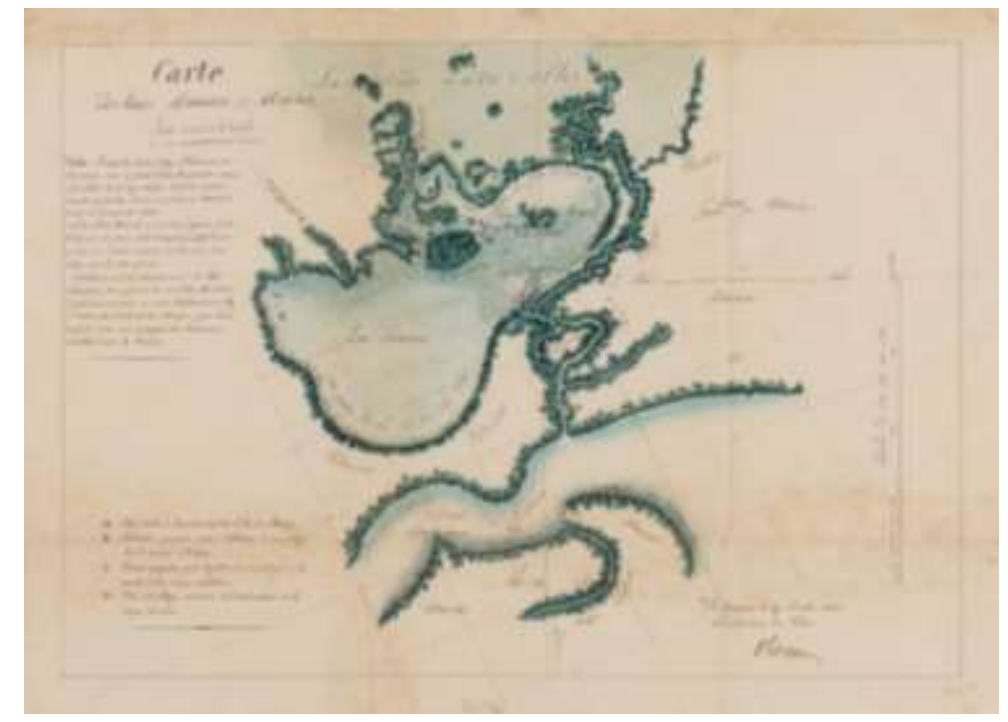

( $\alpha$ ) Map of the Macari and Amapá lakes (with the Choisy Island, where the military post was built).

Cayenne, July 15th, 1836. Archives Nationales d'Outre-M er, 14DFC/865/B

\footnotetext{
32 Ministry of Foreign Affairs, Minister Caetano Maria Lopes Report from the year of 1839, presented to the Legislative General Assembly during the Ordinary Session in 1840.

${ }^{33}$ Ministry of Foreign Affairs, Minister Aureliano de Souza Coutinho. Report from the year of 1840, presented to the Legislative General Assembly during the Ordinary Session in 1841.

${ }^{34}$ In his Memoir, in June 6th, 1841, Gourbeyre, governor of the French Guiana, states that the post of the Amapa Lake had been evacuated by the French in July 10th, 1840. ANOM , GUY 3, Dossier A12 (8).

${ }^{35}$ SILVA. Op. Cit., p. 160.

${ }^{36}$ REIS. Território do Amapá... Op. Cit., p. 93; ROM ANI, Carlos. Aqui começa o Brasil. Rio de Janeiro: Multifoco, 2013, p. 43; RIBEIRO, Duarte da Ponte. Exposição circunstanciada do estado das negociações entre 0 Brasil e a França sobre terrenos contestados pelo lado do rio Oyapock. Rio de Janeiro, 4 de março de 1842.
} 


\section{French Ministerial Reports and Newspapers}

\subsection{Cabanagem in the French newspapers}

As of June 2nd, 1835, the Le Havre newspaper announced the civil war in Pará, highlighting the shooting of Malcher and the horrors that took place in February and beginning of March. It described the situation of the unfortunate Pará inhabitants, who had to emigrate to anywhere, because they believed there would be a new battle with the arrival of an expedition being prepared in Maranhão. Such expedition, to be sent by the Rio de Janeiro Government, would be composed of one frigate and three warships. The Messager, journal, as of July 7th, 1835, mentioned the attitude of the Emperor [sic], who could restore the order in the Province, by sending a Brazilian division composed by several ships and 800 men aboard, upon orders of the commander Taylor. After three days of negotiations, General José [sic] Rodrigues landed in the city, with 480 men, taking ownership. ${ }^{37}$ As of J une 26 th, former president Vinagre surrended. The article stated that this was the end of this insurrection, which lasted six months. However, the Moniteur du Commerce released two days after that recalled the steps of the insurrection and draw the attention for the fact that the white people in Pará was diminishing each day, due to the deaths and emigration. As of August 24th, 1835, Moniteur du Commerce, unlike the Messager, did not mention the state of peace, but the fact that the rebels were already prepared to fight against the forces sent to Rio de Janeiro. In the city of Belém there was lack of foodstuff and there were two French warships in the location, to protect the consul and the other countrymen, after the house of the diplomat Mr. Diniz Crouan was invaded. ${ }^{38}$ The events in Grão-Pará concerned the French authorities and were highlighted by the press, but only in 1836 the insurgents were mentioned more accurately. In the Le Moniteur du Commerce newspaper from January 21st, 1836, the highlight was about the horrors made by Vinagre, who arrived in the city with a group of indigenous

\footnotetext{
${ }^{37}$ This was Marshal Manuel Jorge Rodrigues and his main ally, John Taylor, British mercenary hired by the Brazilian Empire to fight the rebels. CLEARY. Op. Cit., p. 123.

${ }^{38}$ In relation to the attempt of Marshal Rodrigues who, given the lack of enough troops to fight the rebels, tried to involve foreign nations, with their vessels which were at the Port of Belém, see: LIMA. Op. Cit., p. 142-143.
} 
people, committing the most terrible acts of violence. ${ }^{39}$ In the issue from January $23 \mathrm{rd}$, there was a description of Belém as being an anarchy, and they again blamed the indigenous people for the various massacres to the inhabitants. However, the issue from $M$ arch 7th of the same year stated that the insurgents were organized in troops formed by indigenous and black people, and, due to the upheavals in the province, 200 people from Pará had already emigrated to Cayenne. The article also mentioned an extraordinary credit of some millions of francs that the Minister of the Navy and the Colonies had asked to the House of Representatives, including in this amount 116 thousand francs for improvements of the defense of the borders between the Guiana and Pará. According to the article, the Guiana, with a weak garrison with only 460 men, was at high risk and should be protected against the indigenous people from Pará, who had already destroyed the white population of the province. In consonance with the Minister, the 116 thousand francs would be used for bringing a troop with 160 men to Guiana, and a part of it would be sent for the advanced post within the old boundaries of the Amazon. The newspaper believed that the French Empire should protect their subjects from the rebels of Pará, increase the garrison of the colony and take the territory belonging to them for years. ${ }^{40}$

It is difficult to know which was the exact meaning of the word "indigenous" for the newspapers. The French newspapers, between 1835 and 1836, did not define the rebels as Cabanos, but as a rebel group composed by Tapuias indigenous and some black people, fighting against white people and public order ${ }^{41}$ At the time, probably the source for news about the events in Belém were the French consul documents. The interpretation about the groups involved in the insurgency was not different from the interpretation of other foreigners living in Pará, much less the ones from the LuzoBrazilian regional elites. ${ }^{42}$ As of August 1st, 1835, the consul wrote that, during the attack to the town of Vigia, every white person was slaughtered. As of September 8th,

\footnotetext{
39 M oniteur du Commerce was a semiofficial newspaper controlled by the representatives of the colonial aristocracy, published in Paris. JENNINGS, Lawrence. French anti-slavery: the movement for abolition of slavery in France, 1802-1848. Cambridge: Cambridge University Press, 2003, p. 81.

${ }^{40}$ Those newspapers clippings with the articles about the uprising in Pará can be found at ANOM, FM, SG, GUY 41, D 40 (05).

${ }^{41}$ According to Lima, the Cabanos were not a general unit, but an heterogeneous group, comprised of members with different roots and socio-cultural formations, who were not always fighting for the same ideals. LIM A. Op. Cit., p. 263.

${ }^{42}$ The British and Portuguese authorities also mentioned the insurgents as indigenous people, reflecting their contempt for the non- white population. LIM A. Op. Cit., p. 69.
} 
1835, he highlighted that all Portuguese people, as well as some Brazilians, received death threats, and most of the insurgents were Tapuias ${ }^{43}$ mixed with a few slaves. ${ }^{44}$ According to Cleary, the conflict was not a racial issue in the beginning, but it became one. ${ }^{45}$ Only from July 1835 , the uprising became to be seen as a racial conflict by the authorities designated by the Rio de Janeiro central government. But with the arrival of Soares d'Andrea, in April, 1836, to assume the presidency and the command of the weapons in the province, the brutality and the persecution of the rebels was justified as a racial war - white people against black men or civilization against barbarism. From this perspective, the rebels were seen as minor characters, savages, mean, barbaric destroyers, in opposition to the white people, representatives of the civilization. ${ }^{46}$ For the loyalists, every non- white was seen as suspect and the regain of the labor force and the territory presumed the capture and enslavement of the Tapuias and indigenous people, legally free, majority of the population of the province. ${ }^{47}$ The French newspapers communicated the current ideas of that time to their readers and the authorities from the Guiana used, at first, the fear of the indigenous people, that is, the non-white population, for their own purposes: the need to send a deployment to the Amapá lakes region, to protect its inhabitants of the rebels from Pará.

\subsection{French Official Reports}

In relation to the official French correspondence, in a letter dated July 1st, 1835, Cayenne governor, Jean Jubelin, asked the Minister of the Navy and the Colonies if it would not be possible to take advantage of the state of anarchy of Pará to validate the legitimate rights of France up to the Amazon River in the boundaries issue. ${ }^{48}$ It explained that, although the Treaty of 1815 limited the French rights up to the Oiapoque River, there were, for a long time, agricultural lands belonging to the French

\footnotetext{
${ }^{43}$ According to Coudreau, for the French, tapouye was a generic and vulgar term to designate civilized indigenous and mixed races (indigenous and white). COUDREAU. La France équinoxiale. Paris: Challanel Ainé, 1887. p. XIX, footnote.

${ }_{44}$ apud LIM A. Op.Cit., p. 143-144.

${ }^{45}$ CLEARY. Op. Cit., p. 112.

${ }^{46}$ LIM A. Op. Cit., p. 130.

${ }^{47}$ CLEARY. Op. Cit., p. 113.

${ }^{48}$ JUBELIN, Jean. Letter to the Minister of the Navy and the Colonies, July 1st, 1835. ANOM, FM, SG, GUY 33, Dossier (1).
} 
on the right bank of the river. ${ }^{49}$ As the soil in the Uaçá savannahs was much more fertile than the quartiers lands, located close to Cayenne, some residents planned to settle there to raise animals. Jubelin asked the Minister to make the rights of the French prevail over the territory disputed by former treaties. In his view, it would be necessary to end this temporary status of the colony. He insisted that the territory was already a part of the Guiana, despite its low population, and that it was necessary for their economic future success. As it can be observed, the governor and certainly the settlers wanted to take ownership of this large area, suitable for the development of farming, according to the governor.

In a report dated April 11th, 1836, intended to his successor, Laurens de Choisy, Jubelin explained the overall situation of the colony, with some aspects that may help us to understand their concerns and attitudes. ${ }^{50}$ The report explained that the Guiana garrison recently received the addition of 60 infantrymen, so the number of men in the battalion was raised to 565. There were 5 companies, one of them comprised of yolofs who, as he described, were African soldiers..$^{51}$ He mentioned that the Government intended to settle an advanced post southwards to the Oiapoque River, as allowed by the Minister of the Navy and the Colonies in the order dated November 3rd, 1835. The exact location of the post was not decided yet, because they were waiting for the arrival of Commander Penaud, a navy Lieutenant based in Cayenne, who had left in February 7th, 1836, for a reconnaissance of the coastal region. By any means, the military post would serve to set the boundaries and should host at least 50 men. They requested the Board to increase the military forces and, if this was approved, it would meet the needs of the colony. Jean Jubelin concern about the increase of the colonial

\footnotetext{
${ }^{49}$ After the arrival of the Portuguese court, in 1808, to Rio de J aneiro, Dom J oão, the Prince Regent, sent troops composed by Portugal and Pará men, in 1809, with the help of the British navy, to occupy Cayenne in retaliation for the Portugal occupation by the Napoleon troops. The Portuguese, as agreed in the Congress of Vienna, in 1815, returned the colony to the French in November 21st, 1817. CARDOSO, Ciro Flamarion. A Tomada de Caiena vista do lado francês. Revista Navigator, Dossiê Tomada de Caiena, v. 6, n.11, 2010, p. 13-23.

${ }^{50}$ Remise du Gouvernement par M. Jubelin à Laurent de Choisy, ANOM, FM, SG, GUY 03, Dossier A12 (07).

${ }^{51}$ Yolofs were black freed soldiers brought from Senegal. After the 1831 law, prohibiting the slave trade (it was officially prohibited since 1817), France imported men from Senegal to form military companies. In 1840, the yolofs were sent to the Malouet Post, established on the right bank of the Oiapoque River, a region considered unhealthy by the French soldiers. PETITJ EAN ROGET, Hugues. Bonis et africains libres sur le bas Oyapock vers le Milieu du XIXé siècle. Revue Guyanaise d'Histoire et de Geographie, n. 9, janvier, février, mars 1979, p. 43-47.
} 
garrison also seems to be related with the situation of the black people from the ateliers publiques. ${ }^{52}$ They had arrived to the Guiana after the 1831 Law, which prohibited the slave trade and, as expected, should be freed soon. ${ }^{53}$ According to the Governor view, the freed should be divided among the settlers, who needed so much this labor force. Those, in turn, afraid of the presence of free black people alongside their slaves, denied to use freed people in their ateliers. Jubelin explained how he solved the issue: after remaining at the ateliers publiques, many freed slaves would be sent for a mission in Mana, under the responsibility of religious women who would take care of them. ${ }^{54}$

In October 7th, 1836, Du Campe de Rosamel, Minister of the Navy and the Colonies, in response to the Guiana governor, Laurens de Choisy, holding the post since April 11th, 1836, 55 indicated the pressure from Cayenne to settle the military post in the southern limits of the colony. The governor had requested the approval and instructions of the Minister to execute the project. The Minister, in turn, started his reaction, explaining that firstly he would like to remind him about the reasons that lead his predecessor in the Ministry to authorize such procedure. The main reason to establish a post beyond the Oiapoque River had been the occupation of farming lands and, as a reasonable cause for this act, the need to prevent the disorder devastating Pará to reach the Guiana. Furthermore, the Minister raise awareness about a disagreement between Choisy and the Captain of the Body of Engineers, Mr. Ronmy, in relation to the best place to establish the post. Ronmy preferred a location in the vicinity of the Oiapoque River and the Uaçá savannahs, as he considered the location more appropriate to the development of the stock farming and more used to please the French settlers. Choisy, in turn, would have initially being favorable to a place closer to the Amazon River, in the vicinity of the Araguari River, which, due to the high costs, would have been unachievable. However, according to the explanations of the

\footnotetext{
${ }^{52}$ Ateliers were group of slave workers. In the case of ateliers publiques, the slaves were subject to the colonial administration. FOUCK. Op. Cit., p. 58

${ }^{53}$ According to the articles 10 and 11 of the 1831 Law, the black people captured in slave ships who entered the colony after this date should be freed, but they were forced to work for 7 years at the ateliers publiques of the colony. FOUCK. Op. Cit., p. 177-178.

${ }^{54}$ In 1835, 500 black men from the ateliers publiques were delegated to the superior Javouhey of the Mana mission. FORLACROIX, Christian. La fin de la societé esclavagiste em Guyane, 1821-1848. Revue Guyanaise d'Histoire et de Geographie, n. 11, oct., nov., déc. 1979, p. 1-23.

${ }^{55}$ ROSAM EL, Du Campe de. Letter to Laurens de Choisy, October 7th, 1836. ANOM , FM, SG, GUY 171/4.
} 
Minister, a post in the Amapá Lake would bring analogous advantages, and they could observe the moves of the Pará population. It would serve as well to avoid the violations of the limits recently occupied by the French. Du Campe de Rosamel insisted that, for the development of the farming, they should use the vicinities of the post itself, as being suggested by Choisy. He let the Governor choose the location, but he questioned his decision about the location of the auxiliary post, in the island of Maracá, opposed to the recommendation of Captain Ronmy, who suggested the entrance of the Amapá River. ${ }^{56}$ The establishment of the auxiliary post should serve to protect the lower anchorage. Built in the island of Maracá, it had, however, the disadvantage of being farther of the main post, located in the biggest island of the Amapá Lake. Besides commenting on the funding of this construction, the Minister reminded the Governor about the importance of choosing wisely the official for the future post. He should have abilities to keep, in French territory, the Brazilian refugees that were in Cayenne and returned to Amapá with the first expedition, and also the ones to whom the Governor had promised the authorization to settle in the colony territory prospectively. For the Minister, the existence of the military post would be the easiest way to achieve the colonization goals, that is, give to the foreigners the same protection given to the Guiana settlers who would come to the area of the Amapá Lake.

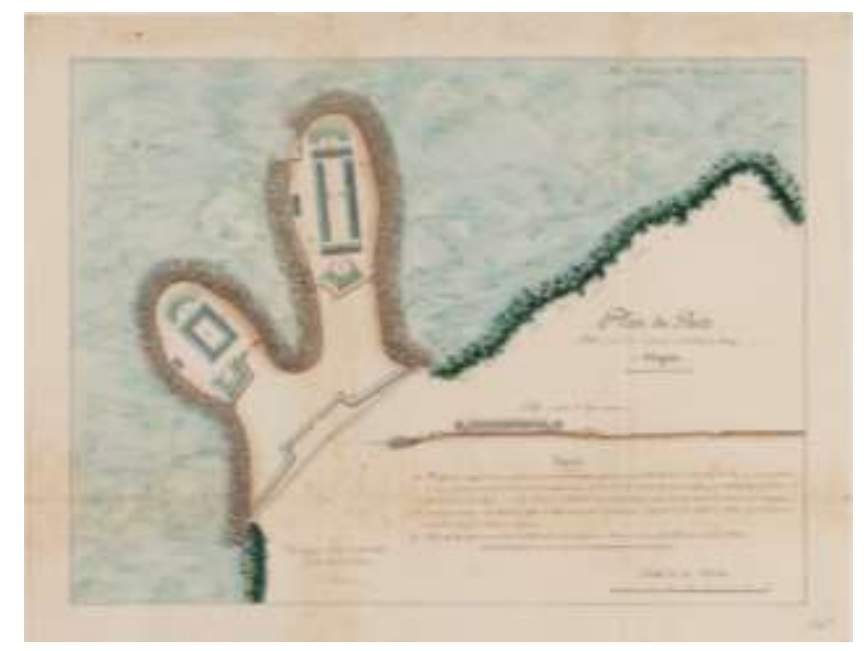

( $\beta$ ) Map of the post established in the northern end of the Choisy Island, at the Amapá (Lake). July 15th, 1836. Author: Thomas Ferdinand Ronmy. Archives Nationales d'Outre-Mer, 14DFC/866/B

\footnotetext{
${ }^{56} \mathrm{About}$ the Romy opinion in relation to the location of the posts, see Correspondence générale du Gouveneur de la Guyane Française. Ordre N 33 , M ay 6th, 1836. ANOM, FM, SG, GUY 171/4.
} 
In a letter from November 11th, 1836, Choisy was rebuked by Minister Rosamel because he offered to inform the Brazilian Government directly about the existence of the post in the Amapa Lake, once Brazil had not made any official complaint to the Cayenne Government. ${ }^{57}$ Putting Choisy in his proper place, the letter emphasized that the government decided to address this issue through diplomatic channels, and that the Brazilian Minister in Paris had sent a note to the French Minister of Foreign Affairs, requesting the withdrawal of the military post. Thus, on the part of Minister Rosamel, there was the need to remind the Guiana governor about the existence of a hierarchy of powers. Even if the territory occupation - as well as the establishment of a military post to protect the settlers - had been Cayenne initiatives, the negotiations with the Empire of Brazil, since they were international borders, should be handled by higher spheres of power, by the Ministry of Foreign Affairs.

We can notice, through the letters between the Cayenne governors and the Minister of the Navy and the Colonies, that the colonial authorities were interested in expanding the French Guiana territory, allowing the development of agriculture and cattle farming in a costal area, which was more favorable. There was a sense of purpose for the project, because the Guiana was never a colony with great economical advantages to the metropolis. ${ }^{58}$ Although, between 1831 and 1847, there had been an upward trend in the colony exports, the commercial exchanges between France and the Guiana reflected only $4 \%$ of the colonial trade. .99

The need to protect the settlers, suggested by the governors, might also be connected to the fear of the French residents to be murdered by the rebels from Pará. According to the French newspapers, the rebels had murdered a large number of white people in Pará and might want to do the same in the Guiana. Ricci explains that the main reason of Cabanagem was the death of the Portuguese people. ${ }^{60}$ This was interpreted by the French as death to white people and, consequently, death to all

\footnotetext{
${ }^{57}$ ROSAMEL, Du Campe de. Letter to Laurens de Choisy, November 11th, 1836. ANOM, FM, SG, GUY $171 / 4$.

${ }_{58}$ SCHWARZBECK, Frank. Französisch-Guayana. Die letzte kontinentale Überseebesitzung in Lateinamerika. Heidelberg: Esprint, 1982, p. 80-82.

${ }^{59}$ FOUCK. Op. Cit., p.164.

${ }^{60} \mathrm{RICCl}, \mathrm{M}$ agda. Fronteiras da nação e da revolução: Identidades locais e a experiência de ser brasileiro na Amazônia (1820-1840). Boletim Americanista, Barcelona, n. 58, 2008, p. 77-95. According to the author, 30.000 people have been killed during Cabanagem, among them, many white people. Ibidem, $p$. 82.
} 
Europeans. In the end of 1835 , many residents had already left Belém. ${ }^{61} \mathrm{~A}$ nominate report, dated January 4th, 1836 and signed by the head of the Internal Central Office, Mr. Lesilly, showed the names, origin and job title of the Brazilian citizens who arrived in Cayenne between May and December, 1835. It was a group consisting of 136 refugees from Pará, including 86 free individuals, among which there were men, women and children, along with 50 black slaves.$^{62}$ Not only white residents left Belém that year. Cabanos - enslaved indigenous, black and mixed people - who were persecuted by the legalistic troops and escaped towards Cabo Norte. ${ }^{63}$ Curt Nimuendaju highlights that, in 1836, a substantial number of Cabanos had taken refuge in the Guiana, some of those staying at the Lower part of Cunani, some others in Cassiporé and two large families had chosen the Curipi River as housing. ${ }^{64}$

In 1838, in a summary of the events, the Pará President mentioned the atmosphere of terror in the province, exactly as the French newspapers did:

\begin{abstract}
...Except for the villages of Cametá, Freguesia de Abaité, Praça de Macapá, and the villages and small settlement in the Xingu River, I am not aware that any other part of this huge province would escape from the fury of those ruthless men; thus, the majority of the mills and farms had been destroyed, the slaves had been dispersed or killed, the cattle had been consumed and the seedbed of the plants which are more important to the daily livelihood had been extinct: in some districts, not only one white individual was left alive; and individuals from every social class are being missed all around. ${ }^{65}$
\end{abstract}

It is difficult to say if it was really that risky, but the atrocities of the rebels were probably exaggerated by the newspapers, by the Pará President and the French Governors, to legitimate the repressive actions and the establishment of a French deployment in the Amapá Lake. There was, however, the real possibility that the desire for freedom of the runaway blacks from the Pará movement could influence the Guiana slaves, in such a way that they would also rebel, or that the number of existing escapes could increase. Even if there was a great regional desire of territorial

\footnotetext{
${ }^{61}$ Ibidem, p. 88.

${ }^{62}$ État nominativ des refugiés de la province du Pará arrivés à Cayenne depuiss le 24 mais 1835. ANOM, FM, SG, GUY 41, Dossier 40 (05).

${ }^{63}$ ROM ANI. Op. Cit., p. 37.

${ }^{64}$ NIMUENDAJÚ, Curt: Die Palikur-Indianer und ihre Nachbarn. Göteborg: Elanders Boktryckerei Aktiebolag, 1926, p. 15.

${ }^{65}$ Speech of the President of the Pará Province in the 1st Session of the Provincial Assembly, in March 2nd, 1838. Santos Restored Typography (undated).
} 
expansion, it is fundamental to consider the fear that the news about the civil war in Pará awakened in the settlers who, in turn, demanded protective measures by the French authorities.

According to Jean Delumeau, "not only the individuals taken separately, but also the communities and the civilizations are committed with a permanent connection to fear". 66 The fear awakened by the slaves in the slave owners was well studied in the historiography about slaveholding societies. We also know that the possibility of a violent uprising was permanent, especially after the events in Haiti, the slave revolts in Jamaica and the Guianas. ${ }^{67}$ Researches in the psychology field show that, in any conflicted human situation, fear can be a result of unbalanced power relations, where the weaker fear the misuse of power from the stronger, and this feeling may lead to total subordination or to an uprising of the weaker part, in order to eliminate the superiority of the stronger part and the unbalanced power relations. This perception of the individual to explain the connection between emotion and action may be applied to international relations, where the countries try to find a state of balance of hegemony with each other ${ }^{68}$ Social or collective fear shall be perceived by the historian as a factor leading to political actions in the international scenario, even if the word fear or concern hardly ever appears in the documents. ${ }^{69}$ The Governing authorities are expected to ensure security, protect the territory and its inhabitants. But fear can also be manipulated by the political power to maintain the order or, in other words, fear can lead to a greater exercise of power and the creation of security strategies. $^{70}$

In relation to the French Guiana, Ciro Flamarion Cardoso draws attention to the collective hysteria lived by the slave owners. ${ }^{71}$ Although the slaving uprisings in this colony did not have the same proportions of the wars in the neighbor colony, the

\footnotetext{
${ }^{66}$ DELUMEAU, Jean. História do medo no Ocidente, 1300-1800: uma cidade sitiada. São Paulo: Companhia das Letras, 2009, p. 12.

${ }^{67}$ SOARES, Carlos Eugênio; GOM ES, Flávio. Sedições, haitianismo e conexões no Brasil escravista. Novos Estudos, n. 63, julho de 2002, p. 131-144.

${ }^{68}$ BORMANN, Patrick; FREIBERGER, Thomas; MICHEL, Judith. Theoretische Überlegungen zum Thema Angst in den internationalen Beziehungen. In:_- (org.). Angst in den internationalen Beziehungen, Göttingen: V\&R University Press, 2010, p. 26.

${ }^{69}$ Ibidem, p. 30-31.

${ }^{70}$ STEARNS, Peter. Fear and History. Historein, v. 8, 2008, p. 17-28.

${ }^{71}$ CARDOSO, Ciro Flamarion. La Guyane française (1715-1815): aspects économiques et sociaux. Guadeloupe: Ibis Rouge Ed. 1999, p. 404.
} 
Dutch Guiana, the panic is understandable, as in 1835 the French Guiana had 16.898 slaves in a population of 21.956 inhabitants. $^{72}$ The threats of the black rebels of the surrounding areas represented, thus. a real danger to the internal order of an enslaving society. The danger was even bigger because the slaves from the French Guiana had already experienced or heard about freedom during the first abolition of slavery, between 1794 and 1802.73 Therefore, I consider that the Amapá post also served as security strategy for the southwest border and as a response to the fear of the residents, who planned to move to the new quartier. Besides the threats in the border with the Pará province, it is well known that, exactly from 1836 on, the black Bonis who wanted to settle in the Lower Oiapoque region caused great fear.

\section{The Bonis in Oiapoque}

There would be no room in this article to talk about the story of the black slaves uprisings striking the Dutch colony by the end of the 18 th Century. ${ }^{74}$ For our analysis, the fundamental is the story about the unsuccessful attempts of the Bonis to take the Lower Oiapoque, a French Guiana territory, between 1836 and 1841.

From 1770 on, under the command of a black man named Boni, a group of slaves wage a bloody war against the Dutch settlers from Suriname. The battle lasted four years and the Bonis, as they became known, were repressed and pushed into the French-Dutch border, which they outreached, and in 1776 they arrived to the right bank of the Maroni River, French territory. ${ }^{75}$ Since the end of the 18th Century, the governing authorities of the French Guiana, a colony where thousands of slaves were controlled and made subject by a few white settlers, were afraid of the arrival of black warriors in their territory. Some French authorities considered to use them in colonization projects, once the population of the Guiana was small, but they never put this idea into practice because of the fear instilled by the black warriors. ${ }^{76}$

\footnotetext{
${ }^{72}$ FOUCK. Op. Cit., p.118.

${ }^{73}$ Slavery was restored in the French colonies in 1802 and definitely abolished in 1848.

${ }^{74}$ VAN LIER: Sociedade de fronteira: uma análise social da história do Suriname. Brasília: Funag/IPRI, 2005. Richard Price and Sally Price had published several works about the Dutch Guiana Saramacas. ${ }^{75}$ FOUCK. Op. Cit., p. 106.

${ }^{76}$ Jornal La Quotidienne, 26/07/1837. Article written by A. de Saint-Quantuel, in May 31st, 1837. ANOM, FM, SG, GUY 44, Dossier E10 (13).
} 
Until the beginning of the 19th Century, the Bonis lived in peace in the area of the Maroni River, far from the residents of the French Guiana coast. The situation has changed in the first decades of the 19th Century. Unlike the Djukas and Saramacas, maroons from Suriname, Bonis did not sign Treaties with the Dutch and were living under the guardianship of the Djukas, who, according to the agreement with the Dutch government, should give back all the new black fugitives in exchange for their own freedom. ${ }^{77}$ Nonetheless, the relation between Bonis and Djukas declined from 1836 on, after the incident involving the French Navy Commander, the pharmacist Leprieur, who, with his expedition, intended to reach the source of the Maroni River, up the Oiapoque River. In the Camopi River, Leprieur and his team met some Bonis, who took them to the Lawa River, where a great misunderstanding took place between both groups. Maybe because he was afraid of being killed, the pharmacist explained that he was officially sent by the colonial authorities to celebrate peace with the Bonis. After some days of celebration, the chief ("gaanman") Gongo sent ten Bonis to inform the Djukas about what has happened. Beeiman, chief of the Djukas, got furious and sent more than 60 warriors to capture Leprieur, but they could not do it, because the Bonis protected him. When he left towards Cayenne, refraining from keep his expedition going, he was accompanied by four Bonis, who wanted to talk directly to the colonial authorities and request permission to settle in the Camopi River, tributary of the Oiapoque River. The Cayenne governor refused to talk to them, sent them to prison and then back to Oiapoque. The Djukas, in turn, required the government of the Dutch colony to meet the promises made by Leprieur on behalf of the French government. As agreed, the Bonis were subject to them, and were not allowed to move from the territory or to celebrate peace with other authorities. The situation reached significant proportions and the Cayenne governor, Laurens de Choisy, was forced to explain the situation to the Suriname governor, who disqualified the pharmacist. ${ }^{78}$

The Bonis refused to believe in the intransigence of the French and, at the end of 1836 , they decided to send again a mission with eight people to Oiapoque, trying to

\footnotetext{
77 PETITJ EAN ROGET. Op. Cit., p. 43-47.

78 HOOGBERGEN, Wim. Frères et ennemis Aluku et Ndjuka de 1710 à 1860. In: COLLOMB, Gérard; JOLOVET, Marie-José (org.). Histoires, identités et logiques ethniques Amérindiens, Créoles et noirs marrons en Guyane. CTHS, Le regard de l'ethnologue, n. 18, 2008, p. 107-140. See also: Copie de la lettre du M. le Gouverneur de Surinam a le M. le Gouverneur de la Guyane française. Paranaibo, September 28th, 1836. ANOM , FM, SG, GUY 44, Dossier E10 (13).
} 
negotiate with the colonial authorities. They claimed to settle in the Camopi River, area which was closer to the slave properties, economically stronger regions, located between Montanha de Prata (M ontagne d'Argent) and Salto de Maripá. In the region of the Lower Oiapoque, most of the properties were fairly small, and each of them had around ten slaves, except the Ouanary properties, which could have, during the 19th

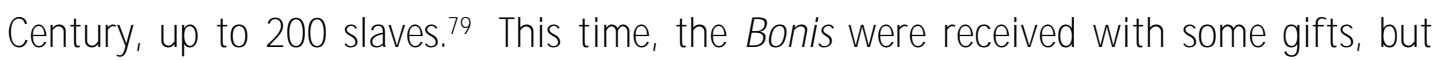
then again were sent away and advised to not coming back anymore. ${ }^{80}$

It is interesting to note, in the subtitle of the plan of the provisional post made by Captain Ronmy, in 1836, the description of the route covered by the Bonis to get to the Lower part of the Oiapoque:

\begin{abstract}
The Bonis settle alongside the Maroni River. To come (here), they went up the Inini River, tributary of the Maroni River, for 2 days. They left their canoes and, to get to Camopi River, tributary of the Oiapoque River, they continue on foot for more 3 days, a path within the forest. Getting there, they could build canoes if they did not find the ones hidden under water. Next, they went down the Camopi River for 5 days. Getting to the Oiapoque River, they needed 5 days to get to the Cafésoca fortress. Altogether, it took them 15 days to get there. ${ }^{81}$
\end{abstract}

In the beginning of 1837, the news about the Bonis from the higher part of the Oiapoque mistreated the indigenous people and were preparing to go down the river spread the fear amongst the residents. In April 1837, under the pressure of the settlers, the governor Laurens de Choisy sent to Oiapoque a deployment with 20 men commanded by the Lieutenant Faivre, with the instruction to kill the Bonis, if they appeared in the region. As of April 29th, once more, the black people sent a mission to the Lower Oiapoque, comprised of nine people and a runaway slave named Modeste, who belonged to a French settler. The idea was to give this slave back to his owner, thus showing good intentions, to live in peace with the settlers of the region. With the intention to give the slave back to the quartier commander, the group went to the Oiapoque Bay, getting there exactly at the same time when the Lieutenant Faivre and his deployment were getting into the river. Without hesitating, the Lieutenant arrested

\footnotetext{
${ }^{79}$ PETITJ EAN ROGET. Op. Cit., p. 43- 47.

${ }^{80}$ FOUCK. Op. Cit., p. 106- 197.

${ }^{81}$ Plan du poste provisoire établit sur I'Oyapock, 1836. Dépot des fortifications des colonies/Guyane (DFC). ANOM, 14DFC/877/A. My translation.
} 
the three Bonis and ordered to capture the other six who were a little further on the river. Among the six Bonis, only one was captured, the other ones could escape, but were injured. The three Bonis arrested were shot the next they, without being heard or judged. The governor from Suriname, Baron van Heckeren, congratulated Laurens de Choisy for his great success. On the other hand, the Attorney General Vidal de Lingendes, as well as many residents of the Oiapoque River were outraged with the summary execution..$^{82}$ The Minister of the Navy and the Colonies called back to France the governor and the Lieutenant Faivre to explain their hostile and brutal attitudes against the black people. In 1838 Faivre was softly judged. Despite the accusations, Choisy was absolved and never went back to Cayenne. ${ }^{83}$

Those dramatic events spread among the settlers the fear of a potential coalition between the Bonis and the slaves from the French Guiana. The new governor of Cayenne, Paul de Nouquer du Camper, took some steps to avoid the approach of the Bonis and calm down the residents, because, as informed, there was a general climate of terror at the Oiapoque quartier. And actually there was the possibility of an aggression on the part of the black people, who had threatened to come back and avenge the death of their comrades. One of the steps taken was to build, in 1837, the Cafésoca fortress in a small island belonging to the French in the middle of the Oiapoque River, in order to avoid the black people to go down the river with their canoes and easily attack the quartier. However, according to a report of the Ministry of the Navy and the Colonies, dated September 22nd, 1838, the Cafésoca post protected the Oiapoque residents against a potential attack from the black people, if they were coming by the river. ${ }^{84}$ However, it would not protect the residents if the black people abandoned their canoes a little bit before the post and crossed the existing woods in the middle of the agricultural lands. Located at both banks of the river, those properties were under the Cafésoca post, and it could not offer any safety if it was a land-based attack. According to the report, hence the importance to establish a new post at one of the banks of the river, mainly because, between May and October 1837,

\footnotetext{
${ }^{82}$ Note. Ministère de la Marine et des Colonies, 29 de julho de 1837. ANOM, FM, SG, GUY 44, Dossier E10 (13), Paris.

${ }^{83}$ HURAULT. Op. Cit., p. 117-121.

${ }^{84}$ Rapport sur le projet d'etablir un poste permanent pour la défense du quartier d'Oyapock, ANOM, $14 \mathrm{DFC} / 70, n^{\circ} 876$.
} 
the Bonis had approached three times from the Cafésoca post. So the new post was built in 1838, in the middle of the agricultural properties, on the right bank of the Oiapoque River, in a place slightly higher, at the height of the Gabaret River, a tributary of the Oiapoque River. In ressonance with to the construction project, made by Captain Ronmy, the fortress will be made from brickwork, with an artillery platform, a hospital, warehouses, and it would be the main military establishment of the quartier. ${ }^{85}$

In January 1839, there was again an attempt of contact between the Bonis and the French authorities in the colony. The black people could approach to Salto de Maripá, close to the Cafésoca fortress, and request authorization - by means of the indigenous people living there - to the commander of the post, to settle at the Camopi River ${ }^{86}$ The request was once more denied, and they were informed by their mediators, the indigenous people, that they should give up the idea of settle at French territory. Nonetheless, a group that did not comply with the situation remained in the Higher part of the Oiapoque River. ${ }^{87}$

As the Bonis were determined to remain in the region, the French decided to take more dramatic measures. In July 1841, a military expedition was organized to attack the group, which in a little higher position in relation to the Cafésoca fortress. The chief of the Bonis got killed, two other men got injured, a woman was captured and the other ones were able to escape. After that, the Bonis gave up settling at the Oiapoque River, and went all to the Lawa River. ${ }^{88}$

In the Oiapoque region, as well as in Cayenne, the administration and the settlers were completely against the idea of allowing the settlement of a population

\footnotetext{
${ }^{85}$ Bulletin officiel de la Guyane Française, Cayenne, 1840, p. 107. According to the Bulletin, the fortress was known as Poste Inferieur and was on the right bank of the Oiapoque River. From that year on, as a tribute to Victor-Pièrre Malouet, governor of the Guiana between 1776-1778, would be named Malouet Fortress. The French map from 1836 mentioned above, indicates the location of a new post - Poste projeté - on the right bank of the Oiapoque River. Because of its location, we assume it is the Post Inferieur. It had already been designed in 1836. The subtitle of this map says that it should be built to protect the center of the Oiapoque quartier. As the Cafésoca fortress is already marked in this project, it probably had been built in 1836 and not in 1837, as mentioned in the 1838 Report, or it was added to the map subsequently.

${ }^{86}$ Letter from the Guiana governor. Cayenne, March 12th, 1839. ANOM, FM, SG, GUY 10, Dossier A3 (02).

${ }^{87}$ According to the report of the Guiana governor, Mr. Gourbeyre, dated August 23rd, 1839, there was a convention between the governments of the Guiana and Suriname, that the French would not allow any group of maroons from the Higher part of the Maroni River to settle at French territory, because this would end their subordination status to the Dutch government. ANOM, GUY 10, Dossier A3 (02).

${ }^{88}$ HURAULT. Op. Cit., p. 117-121.
} 
with almost 400 free and independent black warriors close to the residents. The victories of the maroon blacks on the Dutch army was legendary. As observed by Laussat, the governor, in 1822, the example of Suriname was terrible, because there the black people could form a national organization dealing with Paramaribo as an equal sovereign. ${ }^{89}$ According to Gourbeyre, the French governor, there was also the risk of the black people disturb the good trade relations between the settlers and the indigenous groups who lived under the protection of the French..$^{90}$

Apart from the French imperialism, I consider the construction of the military posts in litigious territory as a precautionary measure taken by the Cayenne government at a moment with a particular climate of insecurity. The posts could not assure total security, yet they could protect, to some extent, the French settlers. Maybe their value was more symbolic than real. However, as a security strategy, they also served the claims of the French government, eager to expand their colonial territory towards the Amazon River. The local events were absorbed by the highest instance of power and the issue began to be addressed by the Ministry of Foreign Affairs of both countries.

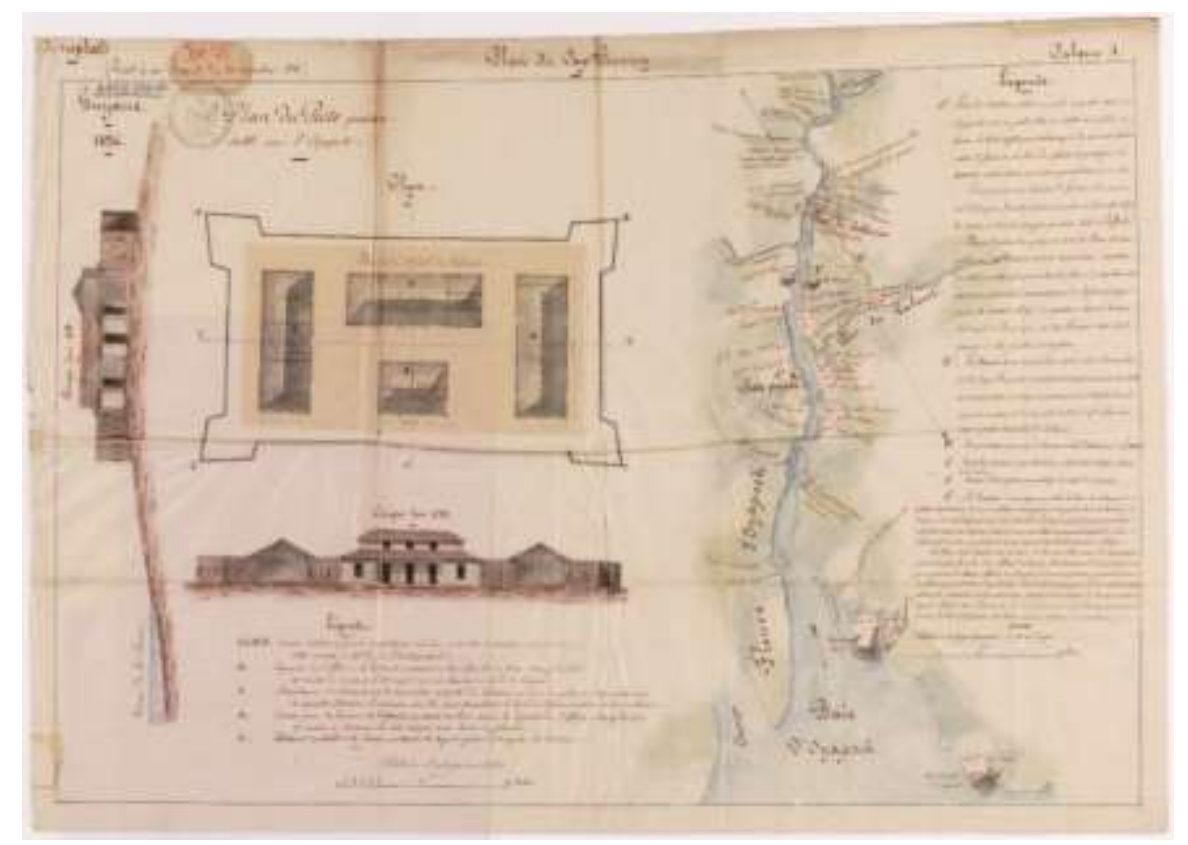

(y) Plan of the provisional post established in the Oiapoque River. Plan of Captain Ronmy.

Archives Nationales d'Outre-Mer, 14DFC/877/A

\footnotetext{
${ }^{89}$ Laussat order, September 2nd, 1822, apud FOUCK. Op. Cit., p. 108.

${ }^{90}$ Gourbeyre Report, August 23rd, 1839. ANOM, FM, SG, GUY 10, Dossier A3 (02).
} 


\section{Recapitulation of the Facts by the French Authorities}

In a letter from 1840, coming from the Ministry of the Navy and the Colonies, there is a recapitulation of the facts and a review of the results deriving from the French decision of establishing the military post in Amapá. ${ }^{91}$ As the other documents covered above, in this document we see again the reasons that led the French to occupy a territory considered litigious, but some new and critical comments in it make clear the complexity of the issue, the interests at stake in the Guiana and also in Paris and the interactions of the different levels of power.

In relation to the establishment of a post in 1836 in the Amapá Lake, between the Oiapoque and Amazon Rivers, the minister highlights again that the main causes were to protect the French settlers established on the right bank of the Oiapoque River since 1817 against the insurgent indigenous groups from the Amazon. While waiting for the demarcation of boundaries which was again discussed after the eviction of the Guiana by the Empire of Brazil, in 1817, the Ministry of the Navy and the Colonies wanted, at the same time, fulfill the wishes of the Cayenne Colonial Council and the local administration, which had announced the possibility of raising livestock there, if the French government provided protection to the settlers. ${ }^{92}$ Not only the Ministry of Foreign Affairs, but also the Ministry of the Navy and the Colonies supported the idea of the Cayenne governors. Besides both ministries, the House of Representatives also supported the decision, by means of an extra credit requested by Mr. Passy, Minister of Trade at the time. Nonetheless, according to the letter, the first idea of the Ministry of the Navy and the Colonies was that the location of the post should not be so close to the Amazon River, with the primary objective to protect the settlers residing at the right bank of the Oiapoque River, and the cattle farming in the Uaçá savannahs. This location probably would have brought good results, without arising the susceptibility of the Brazilian government. However, as Laurens de Choisy, the Guiana governor back then, had chosen the Amapá Lake as ideal location for the post, the Paris government supported his decision. The minister admitted that, as a military deployment, the post

\footnotetext{
${ }^{91}$ Unsigned document, with no official date, but written in pencil on the side the date of February 1st, 1840. ANOM , FM , SG, GUY 33, Dossier 2 (04)

${ }^{92}$ In 1833 the Colonial Council was created, separating the legislative power of the metropolis and the colony. The Guiana had certain legislative autonomy, but the main task of the Council was to discuss and vote for the local budgeting. FOUCK. Op. Cit., p. 16.
} 
had had a certain development: some temporary fortifications, enough to protect the garrison from an attack, had been constructed; a barrack, a hospital and warehouses had been built. The garrison was composed of 50 infantrymen and artillerymen and, after three years, it could be said that the region was salubrious. However, the minister said that there were severe objections against the choice of the location, starting with the communication difficulties via sea. The problem was in the arm of the river connecting the Strait of Maracá to the Amapá Lake. This did not allow the navigation of large ships and, even for the small ones, it was not accessible all year round. The text showed a balance sheet of the expenses that post had already given to the treasuries of the Colony between 1836 and 1839: 200,000 francs. In relation to the agricultural enterprise in Amapá, it highlighted that, by then, it was not significant. It was believed that the soil of the island where the military post had been established was fertile, as well as the savannahs close to the lake, but, until then, there were no herds or agricultural premises in the area. It was alleged that the lack of a treaty for boundaries with Brazil did not encourage the Guiana residents to settle around that area. The minister believed that the lack of trade in the area was due to the lack of an entrepreneurial spirit among the residents.

In a letter to the Minister of the Navy and the Colonies dated February 6th, 1840 to the Minister of Foreign Affairs made clear that the military post in Amapá should be evacuated, as it was the reason for the difficulties in the relations with Brazil and could bring problems to the French political and commercial interests in that part of America. ${ }^{93}$ The letter, which was straightforward, left no other alternative to the minister, who should give to the Cayenne governor the order to withdrawal the garrison from Amapá. The Foreign Ministry would be in charge to notify the French decision to the Emperor minister in Rio de Janeiro.

In February, 1840, in a draft letter to the Cayenne governor, the Minister of the Navy and the Colonies, Guy Victor Duperré, talked about an important issue: that the existing garrison in the Guiana was considered insufficient ${ }^{94}$ The need to provide a deployment to the post in Amapá strongly reduced the military forces required for the public safety in the quartiers with more inhabitants. Even the post located in the

\footnotetext{
${ }^{93}$ Letter to the Minister of Foreign Affairs, February 6th, 1840. ANOM, FM, SG, GUY 33, Dossier 2 (04)

${ }^{94}$ DUPERRÉ, Guy Victor. Draft letter to the French Guiana governor, February, 1840. ANOM , FM, SG, GUY 33, Dossier 2 (04)
} 
Oiapoque River had the number of men cut in half and the residents of this quartier seemed to be alarmed due to the neighborhood of the black Bonis, which was always threatening. Besides that, as noticed by Duperré, the imminent changes in the slavery regimen could require the presence of the deployments in other quartiers of the colony. Therefore, he wrote, the government had decided to withdrawal the deployment of the post in Amapá, along with all the material, and sent it to Cayenne. The Minister decided what to do with the indigenous people living in the area under the French protection, highlighting that the cause had motivated the settlement of the post, the uprising in Pará had already ceased and the territory claimed by France between the Oiapoque and Vincent Pinson ${ }^{95}$ Rivers had not been effectively occupied since then. The letter to the Guiana governor was concluded with the promise to insist with the Ministry of Foreign Affairs about the need of the two to designate commissioners who would demarcate the borders. ${ }^{96}$

By the written communication between the Foreign Minister and the Minister of the Navy and the Colonies and between this latter and the Guiana government, we can notice the initiative of installing military posts in the Amapá Lake and on the right bank of the Oiapoque River came from the Guiana government. To execute this, the authorization of the Paris government was necessary. However, the desire to colonize the Uaçá savannahs was probably an initiative of the French habitants proprietaires, but the governor Laurens de Choisy had chosen by the Amapá Lake because it was closer to the Amazon River. The distance and the difficulties of the maritime transportation between the Amapá Lake and Cayenne, Aproague and the Oiapoque quartiers, the most populated regions of the colony, did not contribute to stimulate the interest of the settlers. The plans of territorial occupation made by Choisy, whether because of strategic errors or greed, did not move forward and also did not bring the economical advantages promised to the metropolis. The Paris government had

\footnotetext{
${ }^{95}$ The French denied to accept the limits defined by the Treaty of Utrecht (1713), establishing the border in the Oiapoque River. They insisted that the border should be in the Araguari River, which they called Vicente Pinzón River. About this issue, see the work of SILVA, Joaquim Caetano da. 0 Oiapoque e 0 Amazonas: uma questão brasileira e francesa. Campinas, IFCH - UNICAM P/ Secult, 2010.

${ }^{96}$ According to Arnaud, the banks of the lower courses of the rivers which flows into the Atlantic, including the Amapá River, undergo ongoing changes mainly due to the volume of sedimentation carried by the stream of the Amazon River. The Amapá Lake, in which island the French settled the military post became a canal with river appearance and the remains of this post were buried in the 20th Century by alluvial soils. ARNAUD, Espedito. Os índios Palikúr do rio Urucauá: tradição tribal e protestantismo. Belém: Museu Paraense Emílio Goeldi, Publicações Avulsas nº 9, 1984.
} 
authorized the colonial undertaking of 1835 , initially considering the potential gains the new colonization could bring, and also because they believed it was the right time to resume the negotiations with Brazil about the demarcation of lands. Since the Guiana intended to occupy the region, the plans could serve both causes and, internationally, the Pará uprising has served as a reasonable excuse for the attitude of the French government.

After a few years, the Paris government realized that the commercial and political advantages with Brazil were bigger than the occupation of the region of the Amapá savannahs, and accepted to leave Amapá, but the withdrawal only happened in July 10th, 1840. According to the French letters, it seems that it was not easy to persuade the Cayenne governor about this decision. ${ }^{97}$ It was necessary to send more letters demanding the eviction, that would not happen. Finally, the orders from Paris were accepted in relation to the Amapá Lake, but the governor did not withdraw the deployment of the Oiapoque post, neither transferred it to the left bank, which was French territory. According to the governor, there was the need to protect the Oiapoque quartier of potential Bonis attacks.

\section{Final Considerations}

According to Helen Milner, the external policy is the result of a confrontation among several internal players, whether governmental, non-governmental or private. ${ }^{98}$ It should not be seen as a work of a rational and unitary state, because the governments are subject to influences of several players and groups, which use these influences to make their interests prevail..$^{99}$ Taking into account that the State is comprised of different decision units, influenced or pressured by individuals, groups or institutions, they take part, therefore, of the process of formulation and execution of the external policy. ${ }^{100}$ To study this policy means to consider the internal process of each country, the interactions between institution and players and to understand the

${ }^{97}$ GOUBEYRE. Letter to the Minister of the Navy and the Colonies, July 14th, 1840. ANOM , FM, SG, GUY 33, Dossier 2 (4).

${ }^{98}$ MILNER, Helen. Rationalizing politics: the emerging synthesis of international, American, and comparative politics. International Organization, 52, 4, Autumn 1998, p. 759-786.

${ }^{99}$ MANSANI, Roberta de Souza; REIS, Rafael Pons. As teorias das relações internacionais nos estudos de política externa: um breve olhar a partir das perspectivas realista e liberal. Revista Andina de Estudios Políticos, v. IV, n. 1, 2014, p. 20-29.

100 MANSANI, Roberta; REIS, Rafael. Op. cit. 
internal and external reasons leading the government representatives to make certain decisions on an international basis. In this light, the international sphere becomes multidimensional and the national interests become changeable, and may vary over time, depending on the internal and external interests at stake. From the 20th Century and especially today, the liberal or pluralist theories about the formulation and execution of governmental external policies seem to be devoted to consider the participation of the civil society in such policies. However, I consider fundamental to analyze the instances of power and the role of individuals and groups in the process of formulation and execution of the external policies also in the period studied here. In my personal opinion, it is not possible to interpret the decision of the French government in 1835/36 for the establishment of a military post in the Amapá Lake, and later, in 1837, of another post on the right bank of the Oiapoque River, as being a unitary policy of the Paris government, looking for territorial expansion. This kind of approach would leave unanswered some factors such as, for example, the moment of the territorial occupation, the choice of location of the two military posts, the year of the establishment, the decision of the French, in 1840, to abandon the most advanced post, in the Amapá Lake, but not the post on the right bank of the Oiapoque River, the Malouet fortress.

By reading the French governmental letters, it can be noticed that the French occupation of the French-Brazilian Boarding was much more complex and dynamic, exposing the interrelations and articulations among the different branches of power expressed in the political and socioeconomic practices observed in the Amazonian geographical area. The French central power, here represented by the Ministry of Foreign Affairs, was influenced in its international policy by the Ministry of the Navy and the Colonies which, in turn, has been put under pressure by the Cayenne governing authorities and the economic interests of the Guiana land owners. Furthermore, those land owners, being afraid of the slaves to run away, required the colonial government to take measures to protect them against the Bonis and Cabanos. The response from Brazil and Great Britain, which did not look favorably to the French expansion in the Amazon, forced the Paris government to reconsider the France interests. The politic and economic relations with Brazil were more significant and beneficial than the ambitions of governing authorities and residents of a colony which was never a significant player in the French economy. After the Pará pacification, the failure to populate the 
occupied area and the removal of the Bonis from the Lower part of the Oiapoque River, the region of the Amapá lakes was unoccupied. The decision was made in 1839 by the Paris government, but its execution, depending on the Guiana governor, only took place when the internal issues were solved, that is, after the great social fear diminished.

Data de recebimento do artigo: 09/12/2015

Data de aprovação do artigo: 20/04/2016

\section{References:}

\section{Primary Sources:}

\section{Center for Research Libraries. Brazilian Government Document Digitalization Project.}

- Ministerial Reports (1821- 1960). Foreign Affairs (1830-1960)

Available on: http://www-apps.crl.edu/brazil/ministerial/rela\%C3\%A7oes exteriores

Minister José Ignacio Borges. Report from the year of 1835, presented to the Legislative General Assembly during the Ordinary Session in 1835. Published in 1836

Minister Antonio Paulino Lima de Abreu. Report from the year of 1836, presented to the Legislative General Assembly during the Ordinary Session in 1837.

Minister Candido Baptista de Oliveira. Report from the year of 1838, presented to the Legislative General Assembly during the Ordinary Session in 1839.

Minister Caetano Maria Lopes Gama. Report from the year of 1839, presented to the Legislative General Assembly during the Ordinary Session in 1840.

Minister Aureliano de Souza Coutinho. Report from the year of 1840, presented to the Legislative General Assembly during the Ordinary Session in 1841.

- Provincial Presidential Reports (1830-1930). Pará

Available on: http://www-apps.crl.edu/brazil/provincial/par\%C3\%A1

Speech of the President of the Pará Province in the 1st Session of the Provincial Assembly, in March 2nd, 1838. Santos Restored Typography (undated). 


\section{Archives Nationales d'Outre-Mer}

Fonds Ministériel, Série Géographie Guyana (GUY): 03, 10, 33, 41, 44, 171/4

Dépot des fortifications des colonies/Guyane (DFC):

- Carte des Lacs Macari et Mapa. Cayenne, 15 Juillet 1836, 14DFC/865/B

- Plan du poste établi sur la pointe septentrionale de lî̂le de Choisy à Mapa. 15 juillet 1836. $14 \mathrm{DFC} / 866 / \mathrm{B}$

- Plan du poste provisoire établit sur l'Oyapock, 1836. 14DFC/877/A

\section{Bibliothèque numérique Manioc / SCD Université Antilles}

- Bulletin officiel de la Guyane Française, Cayenne, 1840.

Available at: https://issuu.com/scduag/docs/fra11248.1

\section{Bibliography}

ARNAUD, Espedito. Os índios Palikúr do rio Urucauá. Tradição tribal e protestantismo. Belém: Museu Paraense Emílio Goeldi, Publicações Avulsas Nº 9, 1984.

BEZERRA NETO, J osé Maia. Ousados e insubordinados: protesto e fugas de escravos na Província do Grão-Pará - 1840/1860. Topoi, Rio de Janeiro, v. 2, 2001, p. 73112.

BORM ANN, Patrick; FREIBERGER, Thomas; MICHEL, Judith. Theoretische Überlegungen zum Thema Angst in den internationalen Beziehungen. In:__ (org.). Angst in den internationalen Beziehungen. Göttingen: V\&R University Press, 2010.

CARDOSO, Ciro Flamarion. La Guyane française (1715-1815). Aspects économiques et sociaux. Guadeloupe: Ibis Rouge Ed., 1999.

. A Tomada de Caiena vista do lado francês. Navigator, Dossiê Tomada de Caiena, v. $6, n^{\circ} 11,2010$, p. 13-23.

CLEARY, David. "Lost Alltogether to the civilized world": Race and the Cabanagem in Northern Brazil, 1750 to 1850. Comparative Studies in Society and History, v. 40, n. 1, Jan. 1998, p. 109-135.

COUDREAU, Henry. La France Équinoxiale. Paris: Challanel Ainé, 1887.

DELUMEAU, Jean. História do medo no Ocidente, 1300-1800: uma cidade sitiada. São Paulo: Companhia das Letras, 2009. 
FORLACROIX, Christian. La fin de la societé esclavagiste em Guyane, 1821-1848. Revue Guyanaise d'Histoire et de Geographie, n 11 , oct., nov., déc. 1979, p. 1-23.

FOUCK, Serge Mam Lam. La Guyane française au temps de l'esclavage, de l'or et de la francisation (1802-1946). Guadeloupe: Iris Rouge Éditions, 1999.

HARRIS, Mark. Rebellion on the Amazon: The Cabanagem. Race and Popular Culture in the North of Brazil, 1798-1840. New York: Cambridge, 2010.

HOOGBERGEN, Wim. Frères et ennemis Aluku et Ndjuka de 1710 à 1860. In: COLLOM B, Gérard; JOLIVET, Marie-José (org.). Histoires, identités et logiques ethniques Amérindiens, Créoles et Noirs Marrons en Guyane. CTHS, Le regard de l'ethnologue, n 18, 2008, p. 107-140.

HURAULT, Jean. Histoire des noirs réfugiés Boni de la Guyane française. Revue française d'histoire d'outre-mer, tome 47, n. 166, premier trimestre, 1960, p. 76-137.

JENNINGS, Lawrence. French anti-slavery: the movement for abolition of slavery in France, 1802-1848. Cambridge: Cambridge University Press, 2003.

LIMA, Leandro Mahalem. Rios Vermelhos. São Paulo: Faculdade de Filosofia, Letras e Ciências Humanas, Universidade de São Paulo, 2008 Tese (Mestrado em Antropologia).

MANSANI, Roberta de Souza; REIS, Rafael Pons. As teorias das relações internacionais nos estudos de política externa: um breve olhar a partir das perspectivas realista e liberal. Revista Andina de Estudios Políticos, v. IV, n. 1, 2014, p 20-29.

MILNER, Helen. Rationalizing politics: the emerging synthesis of international, American, and comparative politics. International Organization 52, 4, Autumn 1998, p. 759-786.

NIMUENDAJÚ, Curt: Die Palikur-Indianer und ihre Nachbarn. Göteborg: Elanders Boktryckerei Aktiebolag, 1926.

PETITJEAN ROGET, Hugues. Bonis et africains libres sur le bas Oyapock vers le milieu du XIXé siècle. Revue Guyanaise d'Histoire et de Geographie, n. 9, janvier, février, mars 1979, p. 43-47.

PINHEIRO, Luís Balkar Sá Peixoto. De vice-reino a Província: tensões regionalistas no Grão-Pará no contexto da emancipação política brasileira. Somanlu, Revista de Estudos Amazônicos, v.1, n. 1, 2000, p. 83-107. 
PRADO JÚNIOR, Caio. Evolução Política do Brasil e outros estudos. São Paulo: Brasiliense, 1977 (1 edição: 1933).

REIS, Arthur Ferreira. A Amazônia e a cobiça internacional. Rio de Janeiro: Record, 1968.

. Território do Amapá. Rio de Janeiro: Imprensa Nacional, 1949.

RIBEIRO, Duarte da Ponte. Exposição circunstanciada do estado das negociações entre 0 Brasil e a França sobre terrenos contestados pelo lado do rio Oyapock. Rio de Janeiro, 4 de março de 1842. Biblioteca Nacional. Rio de Janeiro, Brasil. Seção de Manuscrito.

RICCl, Magda. Llagas de guerra y actos de fe política: La "Cabanagem" en la narrativa historiográfica y antropológica. Boletín Americanista, Año LXII 1, n. 64, Barcelona, 2012, p. 33-57.

.Fronteiras da nação e da revolução: identidades locais e a experiência de ser brasileiro na Amazônia (1820-1840). Boletim Americanista, n. 58, Barcelona, 2008, p. 77-95.

ROM ANI, Carlos. Aqui começa o Brasil. Rio de Janeiro: Multifoco, 2013.

SCHWARZBECK, Frank. Französisch-Guayana. Die letzte kontinentale Überseebesitzung in Lateinamerika. Heidelberg: Esprint, 1982.

SILVA, Joaquim Caetano da. 0 Oiapoque e o Amazonas: uma questão brasileira e francesa. Campinas: IFCH - UNICAMP/ Secult, 2010. (4 edição organizada e coordenada por Paulo Miceli e Janaina Camilo).

SOARES, Carlos Eugênio; GOMES, Flávio. Sedições, haitianismo e conexões no Brasil escravista. Novos Estudos, nº 63, p. 131-144, julho de 2002.

STEARNS, Peter. Fear and history. Historien, v. 8, 2008, p. 17-28.

VAN LIER: Sociedade de fronteira: uma análise social da história do Suriname. (Tradução de Mary Amazonas Leite de Barros). Brasília: Funag/IPRI, 2005.

WALCKENAE, Barão de. Mémoire sur les nouvelles découvertes geographiques faites dans la Guyane Française et sur le nouvel établissement formet à l'île de Mapa. Nouvelles Annales des Voyages. Dix-neuvième année, 1837, p. 5-17. 